\title{
Blood and Tissue Selenium Determination by Hydride Generation Atomic Absorption Spectrophotometry
}

\author{
A. PECHOVÁ, L. PAVLATA, J. ILLEK \\ Clinic of Diseases of Ruminants, University of Veterinary and Pharmaceutical Science Brno, \\ Czech Republic \\ Received May 10, 2005 \\ Accepted November 10, 2005
}

\begin{abstract}
Pechová A., L. Pavlata, J. Illek: Blood and Tissue Selenium Determination by Hydride Generation Atomic Absorption Spectrophotometry. Acta Vet. Brno 2005, 74: 483-490.

The aim of the study was to optimize the method of blood and tissue selenium determination in ruminants, and to implement it in research and diagnostic practice. A method was developed for selenium determination by hydride generation atomic absorption spectrophotometry (HG-AAS) in full blood, blood plasma and serum, the liver, skeletal muscle tissue, the myocardium, and the kidneys after wet mineralization of samples in a closed nitric acid and hydrogen peroxide system and subsequent hydrogen chloride reduction. Hydride generation was performed by $1 \%$ sodium borohydride. The resulting selenium hydride was drawn off under inert atmosphere into a flameheated quartz T-tube to atomize; absorbance at $196 \mathrm{~nm}$ wavelength was measured by an optic system with deuterium lamp background correction. The measurements were verified by using diverse types of reference materials with declared selenium concentration and by a method of yield measurement of calibration solution addition in mineralized samples. The results corresponded with the stated values at the $95 \%$ probability level for all reference materials used. This methodology is acceptable as to both the detection limit $\left(0.762 \mu \mathrm{g} \cdot \mathrm{l}^{-1}\right)$ and the error of measurement (4.6-15\%) required for authorized use in research as well as clinical and preventive livestock medicine. The practical potential of the method was documented in a group of calves supplemented with two different forms of selenium.
\end{abstract}

AAS, liver, muscle, myocardium, microwave mineralization

While the initial interest in selenium research focused on selenium toxicity, the activity of selenium as an essential element needed by all live organisms was discovered only later.

Various selenium-deficit-induced diseases were diagnosed in different animal species. The most frequent ones are muscle dystrophy, observed in most animal species, liver necrosis (pigs, poultry, mice, and rats), microangiopathy (pigs), exudative diathesis (poultry), pancreatic fibrosis (poultry), and placental retention (ruminants). The current research is characterized by an intensive focus on selenium metabolism.

With the view to objectify the selenium status in animals, at both the levels of selenium deficit and selenium toxicity, the interest in a direct selenium determination in tissues and biological fluids of various animal species has recently been increasing. There are a number of selenium determination methods (spectrophotometry, fluorometry, AAS, ICP, gas chromatography, polarography etc.). The most frequently used ones are: fluorometry (Rodriguez et al. 1994; Kuricová et al. 2003), atomic absorption spectrophotometry (Dočekalová et al. 1991; Milde et al. 2002), and hydride generation atomic absorption spectrophotometry.

The last method is based on an analyte reduction producing a liquid hydride, its conversion into gas, and a subsequent atomization in the optical path of an atomic absorption spectrophotometer. The analyte is thus separated from the matrix, and a higher concentration in absorption medium compared with classical AAS arrived at. This leads to an increase in

\footnotetext{
Address for correspondence:

Doc. MVDr. Alena Pechová, CSc.

Clinic of Diseases of Ruminants

Faculty of Veterinary Medicine

University of Veterinary and Pharmaceutical Sciences Brno

Palackého 1-3, 61242 Brno, Czech Republic
}

Phone: +420541562405

Fax: +420 541562413

http://www.vfu.cz/actavet/actavet

htmhttp://www.vfu.cz/acta-vet/actavet.htm 
sensitivity and a considerable reduction of interference. Optimum selenium hydride release depends on the form of the analyte and solution acidity. Tetravalent selenium ( $\left.\mathrm{Se}^{\mathrm{IV}}\right)$ only can hydridize, and therefore the other selenium forms $\left(\mathrm{Se}^{\mathrm{II}}, \mathrm{Se}^{\mathrm{VI}}\right)$ must be converted to this form. Hydrogen chloride is most often utilized for this conversion. Sodium borohydride in an acidic medium is utilized for the hydride generation proper. The reaction is as follows:

$$
\begin{aligned}
& \mathrm{NaBH}_{4}+\mathrm{HCl}+3 \mathrm{H}_{2} \mathrm{O} \rightarrow \mathrm{H}_{3} \mathrm{BO}_{3}+\mathrm{NaCl}+8 \mathrm{H} \\
& \mathrm{Se}^{\mathrm{IV}}+8 \mathrm{H} \rightarrow \mathrm{SeH}_{4}+2 \mathrm{H}_{2}
\end{aligned}
$$

The aim of this study was to optimize the method of blood and tissue selenium determination in ruminants, and to implement the method in research and diagnostic practice.

\section{Materials and Methods}

\section{Chemicals and solutions}

The samples were mineralized by a mixture of $\mathrm{H}_{2} \mathrm{O}_{2}$ - hydrogen peroxide $30 \%$ purris p.a., ACS not stabilized > $30 \%$ (Fluka) and $\mathrm{HNO}_{3}$ - nitric acid purris p.a. $65 \%$ (Fluka). The mixture we used is described in more detail as part of the methodology below. The samples were reduced using $\mathrm{HCl}$ hydrochloric acid $35 \%$ p.a. (Carlo Erba). The hydride generation proper was done using $\mathrm{NaBH}_{4}$ - sodium borohydride purum p.a. (Fluka) - solution stabilized with the help of sodium hydrate p.a. (Lachema).

Selenium calibration solutions were prepared by diluting the stock solution (selenium atomic spectroscopy standard solution (Fluka), concentration $1.000 \mathrm{~g} \cdot 1^{-1}$ ) consecutively.

Verification of results was based on the following reference materials: NYC 704121, 404109 lyophilized blood (Nycomed, Norway), beef liver CRM No. 12-2-01, beef liver SRM 1577b (NIST, USA), lyophilized animal blood IAEA - A - 13 (IAEA, Vienna).

\section{Devices and equipment}

The selenium determination was performed using an atomic absorption spectrophotometer SOLAAR 939 (Unicam, Great Britain). Sample preparation by microwave-digestion-technique wet mineralization in a closed system was performed using an MLS-1200 device (Milestone, Italy).

\section{Analyzed samples}

Blood samples collected from the cows kept at the Clinic of Diseases of Ruminants, University of Veterinary and Pharmaceutical Sciences Brno, were analyzed. Blood was sampled from v. jugularis into disposable heparin test-tubes. Tissues were collected immediately after slaughter and frozen until laboratory processing.

The last section of the paper presents the results of a practical application of the method in evaluating the effect of supplementation of different forms of selenium on the selenium concentrations in blood and selected tissues of calves weighing $55-65 \mathrm{~kg}$, divided in 3 groups. The first group was controls. The calves in the second group were given inorganic selenium parenterally at the start of the experiment (Selevit inj. ad us. vet., natrii seleni anhydricus $2.2 \mathrm{mg}$, tocoferoli acetas $25 \mathrm{mg}$ per $1 \mathrm{ml}$ ), the dose being $20 \mathrm{ml}$ per animal, i.e. the total dose was 40 $\mathrm{mg}$ Se per animal. The calves in the third group were administered selenium orally in the form of yeast (SELPLEX, Alltech, selenium $1,000 \mathrm{mg} \cdot \mathrm{kg}^{-1}$ ) for two months, the daily dose being $0.6 \mathrm{mg}$ Se per animal, resulting in the total dose of $36 \mathrm{mg}$ of selenium per animal. The animals were slaughtered at the end of the experiment and tissues were collected for analysis. Blood samples were taken and analyzed at the start of the experiment and after two months of its duration.

\section{Results}

\section{Method for the determination of selenium}

A method was developed for the determination of selenium concentrations in blood and selected tissues of cattle. Selenium determination was performed in three basic steps: mineralization of samples, reduction of selenium contained in the mineralized sample, and the hydride technique measurement proper.

\section{Mineralization of samples}

The samples were subjected to a wet microwave mineralization in a closed system of nitric acid and hydrogen peroxide medium. The amount of the sample and the composition of the mineralization mixture were optimized for individual tissues and blood: 
a) Whole blood $-2 \mathrm{ml}$ heparinized blood $+5 \mathrm{ml} \mathrm{HNO}_{3}+2 \mathrm{ml} \mathrm{H}_{2} \mathrm{O}_{2}$

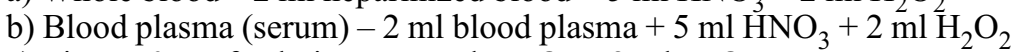

c) Liver $-0.5 \mathrm{~g}$ fresh tissue $+5 \mathrm{ml} \mathrm{HNO}_{3}+2 \mathrm{ml} \mathrm{H}_{2} \mathrm{O}_{2}$

d) Skeletal muscle tissue $-2.0 \mathrm{~g}$ fresh tissue $+5 \mathrm{ml} \mathrm{HNO}_{3}+2 \mathrm{ml} \mathrm{H}_{2} \mathrm{O}_{2}$

e) Myocardium - $2.0 \mathrm{~g}$ fresh tissue $+5 \mathrm{ml} \mathrm{HNO}_{3}+2 \mathrm{ml} \mathrm{H}_{2} \mathrm{O}_{2}$

f) Kidney (cortex) - $0.5 \mathrm{~g}$ fresh tissue $+5 \mathrm{ml} \mathrm{HNO}_{3}+2 \mathrm{ml} \mathrm{H}_{2} \mathrm{O}_{2}$

The mineralization of all sample types was based on an integrated programme, as presented in Table 1. The completion of mineralization was verified by checking the mineralization product for purity and absence of solid corpuscles. The next important step following the mineralization was the evaporation of acid remaining in the sample. The sample evaporation was performed by microwaves in the same device in which the mineralization proper proceeded while the classical rotor was replaced by an evaporation one (Table 2). The mineralization product was evaporated to a final volume of approximately $200 \mu \mathrm{l}$ and transferred quantitatively into $5 \mathrm{ml}$ of water solution in a disposable plastic test-tube.

Table 1. Blood and tissue sample mineralization programme

\begin{tabular}{|c|c|c|}
\hline Phase & Tension & Time of duration \\
\hline Step 1 & $250 \mathrm{~W}$ & $2 \mathrm{~min}$ \\
\hline Step 2 & 0 & $2 \mathrm{~min}$ \\
\hline Step 3 & $250 \mathrm{~W}$ & $6 \mathrm{~min}$ \\
\hline Step 4 & $400 \mathrm{~W}$ & $5 \mathrm{~min}$ \\
\hline Step 5 & $650 \mathrm{~W}$ & $5 \mathrm{~min}$ \\
\hline Ventilation & - & $2 \mathrm{~min}$ \\
\hline
\end{tabular}

Table 2. Programme for evaporation of mineralized blood and tissue samples

\begin{tabular}{|c|c|c|}
\hline Phase & Tension & Time of duration \\
\hline Step 1 & $400 \mathrm{~W}$ & $1 \mathrm{~min}$ \\
\hline Step 2 & $250 \mathrm{~W}$ & $10 \mathrm{~min}$ \\
\hline Step 3 & $0 \mathrm{~W}$ & $3 \mathrm{~min}$ \\
\hline
\end{tabular}

Reduction of samples

The reduction of selenium in the samples to tetravalent selenium was performed in a hydrochloric acid medium; $5 \mathrm{ml}$ of $20 \% \mathrm{HCl}$ were added to $5 \mathrm{ml}$ of mineralized sample water solution to produce a total volume of $10 \mathrm{ml}$. The sample was left standing at room temperature for at least 1 hour. The sample could be subjected to hydride generation after this treatment.

Hydride generation technique analysis

The hydride generation was performed with $1 \%$ sodium borohydride in $0.1 \% \mathrm{NaOH}$, providing the solution with the necessary stability. Fresh solution must be used; it may be kept in a freezing chamber on a short-term basis. The concentration of hydrochloric acid used in samples and calibration solutions was $10 \%$. The acidic medium provided conditions for the hydride generation, and the resulting selenium hydride was drawn off under inert atmosphere (argon) into a quartz T-tube. The quartz T-tube was flame-heated (acetylene air). Atomization occurred and an optic system was used to measure absorbance at $196.0 \mathrm{~nm}$ of wavelength with an activated deuterium lamp background correction.

The results were evaluated automatically based on a continuous signal measurement. The stages of measurement were set as follows: Standby $-10 \mathrm{~s}$, Stabilize $-40 \mathrm{~s}$, Measure $-3 \mathrm{~s}$, Baseline $-40 \mathrm{~s}$. Sample consumption was approximately $4.5 \mathrm{ml}$ per measurement. 


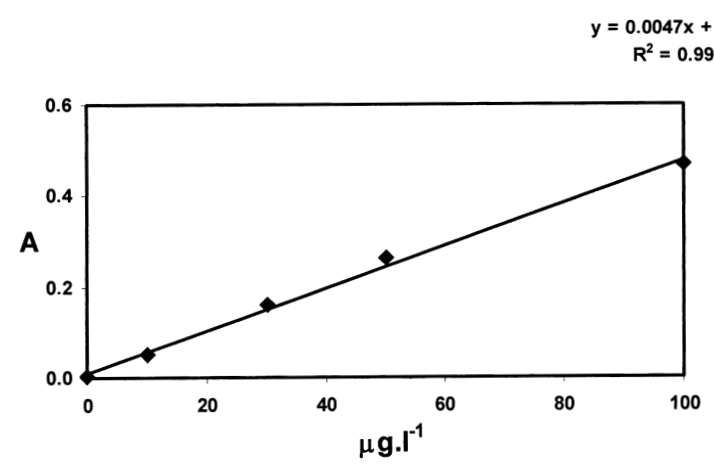

Fig. 1. Calibration line for the determination of selenium by HG AAS (Se concentration in $\mu g \cdot \cdot^{-1} ; \mathrm{A}-$ absorbance)

The selenium concentration was determined using a linear calibration line (the adequacy of the linear relationship was verified by statistical testing). Calibration selenium solutions were prepared by diluting the stock solution (selenium atomic spectroscopy standard solution (Fluka), concentration of $1.000 \mathrm{~g} \cdot \mathrm{l}^{-1}$ ) consecutively. Standard solutions of concentrations of $10,30,50$ and $100 \mu \mathrm{g} \cdot \mathrm{l}^{-1}$ were used. An example of a linear calibration line is shown in Fig. 1. Measurements were verified using diverse types of reference materials with stated selenium concentrations. Results of the reference sample analysis are shown in Table 3. The obtained values corresponded with the stated values at the $95 \%$ probability level for all reference materials used.

Table 3. Comparison between the determined Se concentrations and the stated values for individual reference materials

\begin{tabular}{|l|c|c|}
\hline \multicolumn{1}{|c|}{ Reference material } & Stated value & Obtained value \\
\hline $\begin{array}{l}\text { Lyophilized blood } \\
\text { Nyc 404107 }\end{array}$ & $\begin{array}{c}80 \mu \mathrm{g} \cdot 1^{-1} \\
(80-91)\end{array}$ & $\begin{array}{c}81.45 \mu \mathrm{g} \cdot \cdot^{-1} \\
(81.45 \pm 4.73)\end{array}$ \\
\hline $\begin{array}{l}\text { Lyophilized blood } \\
\text { Nyc 404109 }\end{array}$ & $79 \mu \mathrm{g} \cdot \mathrm{l}^{-1}$ & $77.50 \mu \mathrm{g} \cdot \mathrm{l}^{-1}$ \\
$(79-84)$ & $0.24 \mathrm{mg} \cdot \mathrm{kg}^{-1}$ \\
Lyophilized animal blood & $0.24 \mathrm{mg} \cdot \mathrm{kg}^{-1}$ & $(0.24 \pm 0.037)$ \\
IAEA-A-13 & $(0.15-0.31)$ & $325.86 \mu \mathrm{g} \cdot \mathrm{kg}^{-1}$ \\
\hline Beef liver & $325 \mu \mathrm{g} \cdot \mathrm{kg}^{-1}$ & $(325.86 \pm 11.56)$ \\
CRM No. 12-1-01 & $(311-339)$ & $0.73 \mathrm{mg} \cdot \mathrm{kg}^{-1}$ \\
\hline Beef liver & $0.73 \mathrm{mg} \cdot \mathrm{kg}^{-1}$ & $(0.73 \pm 0.002)$ \\
SRM 1577b & $(0.67-0.79)$ & \\
\hline
\end{tabular}

The detection limit was defined as a triple of the standard deviation of a duplicate blank sample measurement, which was $0.762 \mu \mathrm{g} \cdot \mathrm{l}^{-1}$. The sensitivity of the method was defined as the linear calibration line gradient, namely $0.0047 \mathrm{~A} / \mu \mathrm{g} \cdot \mathrm{l}^{-1}$. The reproducibility of the method was calculated as the variation coefficient for 10 parallel analyses performed on samples with low and high concentrations of the analyte. The variation coefficient was 4.6 $-15 \%$ depending on the analyte concentration in the sample.

The measurement correctness was verified and possible effects of potential interfering factors were eliminated by spiking the individual matrixes with calibration solutions with the stated selenium content. Results and evaluation of the yield are presented in Table 4 . The yield was good for all samples. 
Table 4. Additions of calibration solutions into mineralized samples with different matrixes $\left(\mu \mathrm{g} \cdot \mathrm{kg}^{-1}\right)$

\begin{tabular}{|l|c|c|c|c|}
\hline \multirow{2}{*}{ SAMPLES } & \multirow{2}{*}{$\begin{array}{c}\text { Measured } \\
\text { concentration } \\
\text { Se }\left(\boldsymbol{\mu} \mathbf{g} \cdot \mathbf{k g}^{-1}\right)\end{array}$} & $\begin{array}{c}\text { Calculated value } \\
\left(\boldsymbol{\mu} \mathbf{g} \cdot \mathbf{k g}^{-1}\right)\end{array}$ & $\begin{array}{c}\text { Measured value } \\
\left(\boldsymbol{\mu} \mathbf{g} \cdot \mathbf{k g}^{-1}\right)\end{array}$ & Yield \% \\
\hline Whole blood & 4.95 & 12.48 & 12.92 & 103.5 \\
\hline Plasma & 9.90 & 16.75 & 16.44 & 98.1 \\
\hline Muscle & 5.48 & 27.74 & 26.52 & 95.6 \\
\hline Myocardium & 17.84 & 33.92 & 31.90 & 94.0 \\
\hline Liver & 19.36 & 34.68 & 32.36 & 92.8 \\
\hline Kidney & 67.24 & 83.62 & 80.34 & 96.9 \\
\hline
\end{tabular}

Results of a practical implementation of the method

The above-described method for the blood and tissue selenium determination in cattle was verified in practice by monitoring the effects of supplementation of different forms of selenium on the selenium concentrations in blood and selected tissues of calves. This section provides only the key measurement results as an illustration. Detailed results of this experiment have already been published (Pavlata et al. 2001). Supplementation of different selenium forms to calves resulted in a very significant increase in full blood selenium concentrations for both selenium forms. In terms of absolute values, a more significant rise occurred after the administration of an oral supplement with yeast-bound selenium, the mean increase being $57 \mu \mathrm{g} \cdot \mathrm{l}^{-1}$, while supplementation of inorganic selenium led to an increase of blood selenium of $22 \mu \mathrm{g} \cdot \mathrm{l}^{-1}$ only. The blood selenium concentration of the controls did not change. Results are presented in Table 5.

Table 5. Concentration of Se $\left(\mu \mathrm{g} \cdot 1^{-1}\right)$ in the blood of calves in the experimental groups at the start and at the end of the experiment (mean \pm standard deviation)

\begin{tabular}{|c|c|c|}
\hline Group & Before supplementation & After 2 months \\
\hline Control & $69.21 \pm 11.22$ & $68.42 \pm 10.70$ \\
\hline Selevit & $53.40 \pm 10.50$ & $75.90 \pm 4.00$ \\
\hline Selplex & $70.25 \pm 12.07$ & $127.50 \pm 16.70$ \\
\hline
\end{tabular}

After the calves were slaughtered at the end of the experiment, selenium concentration in individual tissues and organs was determined. Statistically significant differences were found as to the selenium concentrations in the liver, muscle tissue and the myocardium between the calves which were administered organic selenium (Selplex) orally, and the other two groups. Selenium concentration in the kidneys was similar in all 3 groups. The determined selenium concentrations in different organs are presented in Table 6.

Table 6. Concentration of Se $\left(\mu \mathrm{g} \cdot \mathrm{kg}^{-1}\right)$ in fresh tissues of calves in the experimental groups (mean \pm standard deviation)

\begin{tabular}{|c|c|c|c|c|}
\hline Group & Liver & Kidney & Muscle & Myocardium \\
\hline Control & $213.26 \pm 56.83$ & $991.90 \pm 49.10$ & $92.36 \pm 29.24$ & $121.45 \pm 31.81$ \\
\hline Selevit & $206.54 \pm 36.20$ & $960.62 \pm 36.33$ & $81.42 \pm 12.07$ & $108.30 \pm 9.57$ \\
\hline Selplex & $424.66 \pm 88.42$ & $1050.54 \pm 336.82$ & $263.42 \pm 47.35$ & $251.42 \pm 51.00$ \\
\hline
\end{tabular}

\section{Discussion}

The methodology we have developed is based on producer recommendations concerning individual analytical devices. The use of a closed microwave digestion system has the advantage of minimizing the potential loss of analyte due to an open system mineralization. 
The open and closed system mineralizations were compared in a valuable experiment by Ducros et al. (1994); the correlation coefficient between the two methods was 0.94. The method has the additional benefit of being very fast, which considerably reduces the time necessary for sample processing.

One critical point of the method is the complete evaporation of nitric acid from the sample after the mineralization. In combination with the hydride generation technique, inefficient evaporation leads to an interference due to the nitrogen oxide and signal reduction. Milde et al. (2002) found that the signal reduction corresponding to $0.7 \%$ of $\mathrm{HNO}_{3}$ in the solution is $25 \%$, and the signal reduction corresponding to $7 \%$ may be up to $55 \%$. Excessive evaporation, on the other hand, involves the risk of the loss of analyte. In contrast to other authors (Milde et al. 2002) who recommend the utilization of the mineralization mixture $\mathrm{HNO}_{3}-\mathrm{HClO}_{4}-\mathrm{H}_{2} \mathrm{O}$ in the ratio of $10: 1: 1$, our results suggest that the $\mathrm{HNO}_{3}+\mathrm{H}_{2} \mathrm{O}_{2}$ mixture is sufficient as a universal mixture for the mineralization of organic matrices explored by us.

The method was validated using reference materials with satisfactory results. Due to its simplicity, the method may be recommended for routine selenium determination in biological tissues and fluids and has a potential for wide use in veterinary selenium deficit diagnostics and prevention. The detection limit of $0.762 \mu \mathrm{g} \cdot \mathrm{l}^{-1}$ is comparable to detection limits achieved e.g. with ETA AAS $-2 \mu \mathrm{g} \cdot \mathrm{l}^{-1}$ (Hocquellet and Candillier 1991). Milde et al. (2002) compared different methods of selenium determination in non-mineralized samples by ETA-AAS using three types of modifiers. They determined the following detection limits: $6.29 \mu \mathrm{g} \cdot \mathrm{l}^{-1}$ for $\mathrm{Pd}\left(\mathrm{NO}_{3}\right)_{2}+\mathrm{Mg}\left(\mathrm{NO}_{3}\right)_{2} ; 4.34 \mu \mathrm{g} \cdot \mathrm{l}^{-1}$ for $\mathrm{Ni}\left(\mathrm{NO}_{3}\right)_{2}+\mathrm{Mg}\left(\mathrm{NO}_{3}\right)_{2}$ and $5.132 \mu \mathrm{g} \cdot \mathrm{l}^{-1}$ for $\mathrm{Pd}+$ ascorbic acid. They used a graphite cuvette with a pre-installed pyroplatform. The concentration was determined using the standard addition method. The detection limit achieved by these authors with the hydride generation detection was 0.54 $\mu \mathrm{g} \cdot \mathrm{l}^{-1}$, the reproducibility being $14.2 \%$. The reproducibility recorded by us $(4.6-15 \%)$ corresponds to the values obtained by other authors (5.06-13.25\%; Diaz et al. 1997), the determination method being similar.

Literature on the hydride generation technique mentions interference associated with higher cation concentrations in samples. Since blood is characterized by a relatively high concentration especially of sodium $\left(140-150 \mathrm{mmol} \cdot \mathrm{l}^{-1}\right)$, we tested the potential effect of interference by standard additions into samples with stated selenium concentrations. The yield ranged between 92.8 and $96.9 \%$ for tissues, and even better results were obtained for blood: $98.1-103.5 \%$. These results show that the interference does not play a significant role in association with the method. Milde et al. (2002) detected a decrease in absorbance of approx. $10 \%$ at sodium concentration $4.4 \mathrm{mmol} \cdot \mathrm{l}^{-1}$ and an increase of approx. $20 \%$ at sodium concentration $8.7 \mathrm{mmol} \cdot \mathrm{l}^{-1}$. Although in our blood samples, which were diluted five times consecutively, the estimated concentrations of sodium were very high compared with these values (approx. $30 \mathrm{mmol} \cdot \mathrm{l}^{-1}$ ), no reduction in the signal occurred.

The applicability of the method was confirmed through an experiment, whose results are briefly summed up in this paper. Actual values detected by different authors vary considerably. The pre-supplementation calf blood selenium concentrations found by us ( 50 $\left.-70 \mu \mathrm{g} \cdot \mathrm{l}^{-1}\right)$ were in good accord with the values of $50-80 \mu \mathrm{g} \cdot \mathrm{l}^{-1}$ reported by Stowe and Herdt (1992). On the other hand, the selenium levels detected by Kirk et al. (1995) in newborn calves were considerably higher: $137 \pm 82 \mu \mathrm{g} \cdot \mathrm{l}^{-1}$; their mothers had blood selenium concentrations of $220 \pm 56 \mu \mathrm{g} \cdot \mathrm{l}^{-1}$. Mean selenium concentrations in blood of cows and their calves of $41 \pm 11 \mu \mathrm{g} \cdot \mathrm{l}^{-1}$ to $264 \pm 49 \mu \mathrm{g} \cdot \mathrm{l}^{-1}$, and $52 \pm 16 \mu \mathrm{g} \cdot \mathrm{l}^{-1}$ to $222 \pm 53 \mu \mathrm{g} \cdot \mathrm{l}^{-1}$ respectively, were detected by Pavlata et al. (2003, 2004ab) when studying selenium metabolism in cattle with respect to the mother/calf relationship. Differences between the determined values may be due to the determination methodology, but the level of selenium intake by 
individual calves is an important factor, too, whether they are fed selenium-supplemented feed mixtures, administered selenium in an injection form, or have a natural selenium intake from forage, in which the selenium concentration is affected by the amount of selenium contained in the soil and/or fertilizers. When feeding cattle with selenium-enriched forage, Jukola et al. (1996) found the blood selenium concentrations of different cattle categories to be $183-244 \mu \mathrm{g} \cdot l^{-1}$. Zu st et al. (1996) found the blood selenium concentrations of milk cows to range between 43.9 and $65.3 \mu \mathrm{g} \cdot \mathrm{l}^{-1}$, while the corresponding values were only 13.7 $-17.4 \mu \mathrm{g} \cdot 1^{-1}$ for non-supplemented herds.

The same authors report hepatic selenium concentrations ranging between 1,200 and $2,000 \mu \mathrm{g} \cdot \mathrm{l}^{-1}$ of dry matter. Considering the fact that our results were obtained for fresh matter, these numbers can hardly be compared. Similar values are reported by Salis bury et al. (1991): $280 \mu \mathrm{g} \cdot \mathrm{kg}^{-1}$ for cattle liver, and $920 \mu \mathrm{g} \cdot \mathrm{kg}^{-1}$ for kidneys.

The utilization of different forms of selenium in sheep was compared by Ko enig et al. (1997). Administering selenium contained in yeast, and as a selenite, they found that both chemical forms are almost identically utilizable in ruminants. In contrast to that, diet composition was a significant factor as concentrate-based diets were found to be associated with a significantly higher selenium utilizability compared with forage-based diets.

This method of blood and tissue selenium determination in ruminants may be recommended for a routine selenium determination in biological tissues and fluids. This method is acceptable as to both the detection limit $\left(0.762 \mu \mathrm{g} \cdot \mathrm{l}^{-1}\right)$ and the error of measurement (4.6-15\%) required for authorized use in research as well as clinical and preventive livestock medicine.

\section{Stanovení selenu v krvi a tkáních hydridovou technikou atomové absorpční spektrofotometrie}

Cílem práce byla optimalizace metody na stanovení selenu v krvi a tkáních přežvýkavců a praktické zavedení vyvinuté metody do výzkumu a diagnostické praxe. Byla zavedena metoda stanovení selenu hydridovou technikou atomové absorpční spektrofotometrie (HG AAS) v plné krvi, krevní plazmě a séru, játrech, kosterní svalovině, myokardu a ledvinách po mineralizaci vzorků mokrou cestou $\mathrm{v}$ uzavřeném systému $\mathrm{v}$ prostředí kyseliny dusičné a peroxidu vodíku a jeho následné redukci v prostředí kyseliny chlorovodíkové. Generování hydridů bylo prováděno $1 \%$ natrium borhydridem. Vzniklý selenovodík byl odváděn v inertní atmosféře do křemenné T-trubice vyhřívané plamenem, kde dochází $\mathrm{k}$ atomizaci a pomocí optického systému je měřena absorbance při vlnové délce 196 nm s korekcí pozadí pomocí deuteriové lampy. Ověření správnosti měření bylo provedeno použitím různých typů referenčních materiálů s deklarovanou koncentrací selenu a metodou měření výtěžnosti přídavku kalibračních roztoků do mineralizovaných vzorků. Výsledky u všech použitých referenčních materiálů odpovídaly deklarovaným hodnotám na $95 \%$ hladině pravděpodobnosti. Uvedená metodika vyhovuje z hlediska detekčního limitu $\left(0,762 \mu \mathrm{g} \cdot \mathrm{l}^{-1}\right)$ i chyby stanovení $(4,6-15 \%)$ požadavku pro využití ve výzkumu, klinické i preventivní medicíně hospodářských zvířat. Na skupině telat dotovaných selenem ve dvou různých formách byla rovněž dokumentována možnost praktického využití této metody.

\section{Acknowledgements}

We express our thanks to the employees of the Laboratory Diagnostic Department of the Clinic of Diseases of Ruminants who participated in the laboratory analyses, especially Mrs. Jarmila Samková, whose accurate operation of the analyzer unit was a considerable contribution to the application of the above-described methodology. The research project was supported by the Research Project of the Ministry of Education, Sports and Youth of the Czech Republic MSM6215712403. 


\section{References}

DIAZ JP, NAVARRO M, LOPEZ H, LOPEZ MC 1997: Determination of selenium levels in dairy products and drinks by hydride generation atomic absorption spectrometry: Correlation with daily dietary intake. Food Addit Contam 14: 109-114

DOČEKALOVÁ H, DOČEKAL B, KOMÁREK J, NOVOTNÝ I 1991: Determination of selenium by electrothermal atomic-absorption spectrometry 1. Chemical modifiers. J Anal Atom Spectrom 6: 661-668

HOCQUELLET P, CANDILLIER MP 1991: Evaluation of microwave digestion and solvent-extraction for the determination of trace amounts of selenium in feeds and plant and animal-tissues by electrothermal atomicabsorption spectrometry. Analyst 116: 505-509

JUKOLA E, HAKKARAINEN J, SALONIEMI H, SANKARI S 1996: Blood selenium, vitamin E, vitamin A, and beta-carotene concentrations and udder health, fertility treatments, and fertility. J Dairy Sci 79: 838-845

KURICOVÁ S, BOLDIŽÁROVÁ K, GREŠÁKOVÁ L, BOBČEK R, LEVKUT M, LENG L 2003: Chicken selenium status when fed a diet supplemented with Se-Yeast. Acta Vet Brno 72: 339-346

KOENIG KM, RODE LM, COHEN RDH, BUCKLEY WT 1997: Effects of diet and chemical form of selenium on selenium metabolism in sheep. J Anim Sci 75: 817-827

MILDE D, ŠOBROVÁ M, MACHÁČEK J, STUŽKA V 2002: Optimization of conditions of selenium determination in blood serum by atomic absorption spectrometry. Chem Listy 96: 708-712

PAVLATA L, ILLEK J, PECHOVÁ A 2001: Blood and tissue selenium concentrations in calves treated with inorganic or organic selenium compounds - a comparison. Acta Vet Brno 70: 19-26

PAVLATA L, PRÁŠEK J, PODHORSKÝ A, PECHOVÁ A, HALOUN T 2003: Selenium metabolism in cattle: maternal transfer of selenium to newborn calves at different selenium concentrations in dams. Acta Vet Brno 72: 639-646

PAVLATA L, PECHOVÁ A, DVOŘ́́K R 2004a: Microelements in colostrum and blood of cows and their calves during colostral nutrition. Acta Vet Brno 73: 421-429

PAVLATA L, PRÁŠEK J, FILÍPEK J, PECHOVÁ A 2004b: Influence of parenteral administration of selenium and vitamin $\mathrm{E}$ during pregnancy on selected metabolic parameters and colostrum quality in dairy cows at parturition. Vet Med - Czech 49: 149-155

RODRIGUEZ EM, SANZ MT, ROMERO DC 1994: Critical study of fluorometric determination of selenium in urine. Talanta 41: 2025-2031

SALISBURY CDC, CHAN W, SASCHENBRECKER PW 1991: Multielement concentrations in liver and kidney tissues from 5 species of Canadian slaughter animals. J Assoc Anal Chem 74: 587-591

STOWE HD, HERDT TH 1992: Clinical assessment of selenium status of livestock. J Anim Sci 70: 3928-3933

ZUST J, HROVATIN B, SIMUNDIC B 1996: Assessment of selenium and vitamin E deficiencies in dairy herds and clinical disease in calves. Vet Rec 139: 391-394 